\title{
STRONA PODMIOTOWA CZYNU ZABRONIONEGO NIEPOCZYTALNEGO SPRAWCY
}

Zagadnienie strony podmiotowej czynu zabronionego, którego sprawca znajduje się w stanie niepoczytalności, nie było dotychczas w sposób wyczerpujacy omówione w doktrynie prawa karnego. Problemem tym zajmowano się zazwyczaj dość powierzchownie, najczęściej przy okazji omawiania konstrukcji niepoczytalności lub objaśniania podstaw odpowiedzialności sprawcy niepoczytalnego $\mathrm{w}$ związku $\mathrm{z}$ wprawieniem się $\mathrm{w}$ stan nietrzeźwości lub odurzenia, tj. regulacji art. $31 \S 3$ k.k. ${ }^{1}$ Więcej uwagi zagadnieniu strony podmiotowej niepoczytalnego sprawcy poświęcił ostatnio A. Zoll, który rozpatrywał jej problematykę również w odniesieniu do art. $31 \S 1 \mathrm{k} . \mathrm{k} .{ }^{2}$ Do jego rozważań odniosła się A. Liszewska ${ }^{3}$. Kwestia strony podmiotowej w kontekście niepoczytalności została także poruszona w dwugłosie W. Patryasa i Ł. Pohla dotyczącym normy sankcjonowanej ${ }^{4}$. Poniższe rozważania również nie będą pretendowały do roli uwag wyczerpująco analizujących tytułową problematykę, stanowić one będą jedynie próbę naświetlenia podstawowych problemów rodzących się na jej gruncie.

Na wstępie celowe wydaje się poczynić kilka ustaleń dotyczących samej konstrukcji niepoczytalności w polskim prawie karnym. Ustawodawca, definiując tę konstrukcję w przepisie art. $31 \S 1$ k.k., posłużył się metodą mieszaną, wykorzystującą zarówno psychiatryczne, jak i psychologiczne kryteria niepoczytalności. Zgodnie z kryterium psychiatrycznym niepoczytalność może być powodowana przez chorobę psychiczną, upośledzenie umysłowe lub inne zakłócenie czynności psychicznych. Kryterium psychologiczne wyznacza natomiast powstające na gruncie wymienionych przyczyn stany, które uzasadniaja przyjęcie niepoczytalności sprawcy czynu zabronionego. Stany te to

\footnotetext{
${ }^{1}$ Wspomnieć należy tu przede wszystkim trzech autorów: M. Tarnawski, Problem winy niepoczytalnego i o poczytalności zmniejszonej, odurzonych alkoholem lub innymi środkami odurzajacymi, „Ruch Prawniczy, Ekonomiczny i Socjologiczny” 1975, z. 2; T. Kaczmarek, Spory wokót charakteru odpowiedzialności karnej sprawców przestẹstw popełnionych w warunkach zawinionej niepoczytalności, „Państwo i Prawo” 2004, z. 1; J. Lachowski, Przejawy obiektywizacji odpowiedzialności karnej w k.k. z 1997 r., ,Studia Prawnicze” 2006, z. 1.

${ }^{2}$ Zob. A. Zoll, Kwalifikacja prawna czynu i wina niepoczytalnego sprawcy, w: J. Majewski (red.), Okoliczności wytaczajace winę: materiaty VI Bielańskiego Kolokwium Karnistycznego, Toruń 2010.

${ }^{3}$ Zob. A. Liszewska, Strona podmiotowa czynu $i$ wina a niepoczytalność, w: P. Kardas, T. Sroka, W. Wróbel (red.), Państwo prawa i prawo karne. Ksiega jubileuszowa Profesora Andrzeja Zolla, t. 2, Warszawa 2012, s. 631-645.

${ }^{4}$ Zob. W. Patryas, Ł. Pohl, Dwugtos $w$ sprawie normy sankcjonowanej, „Ruch Prawniczy, Ekonomiczny i Socjologiczny" 2006, z. 4, s. 173-189.
} 
niemożność rozpoznania znaczenia czynu oraz niemożność pokierowania swoim postępowaniem. Dodać nadto należy, że przepis art. $31 \S 1 \mathrm{k} . \mathrm{k}$. wymaga jeszcze koincydencji czasowej stanu niepoczytalności z momentem popełnienia czynu zabronionego, co oznacza, że w chwili popełnienia czynu zabronionego sprawca - na skutek wspomnianych przyczyn - ma być pozbawiony możliwości rozpoznania znaczenia tego czynu lub pokierowania swoim postępowaniem. Tylko wtedy dopuszczalne jest przyjęcie, że znajdował się on $\mathrm{w}$ stanie niepoczytalności, który uniemożliwia przypisanie sprawcy winy.

W wypadku kryterium psychologicznego słusznie zwraca się uwagę, że ustawodawca tylko pozornie posłużył się zwykłą alternatywą. W rzeczywistości mamy tu do czynienia $\mathrm{z}$ alternatywa w koniunkcji z implikacją ${ }^{5}$. Niemożność rozpoznania przez sprawcę znaczenia jego czynu zawsze bowiem pociaga za sobą niemożność pokierowania własnym postępowaniem. Nie zachodzi jednak zależność przeciwna - tzn. możliwa jest sytuacja, gdy sprawca wprawdzie rozpoznaje znaczenie swojego czynu, nie jest jednak w stanie pokierować swoim postępowaniem ${ }^{6}$. Niemożność rozpoznania znaczenia czynu może przybrać dwie postacie. Sprawca może nie być w stanie rozpoznać ontologicznego znaczenia swojego czynu. Nie uświadamia sobie wówczas zależności kauzalnych i fizycznych swojego zachowania. Krótko mówiąc, nie wie, co jego czyn oznacza w rzeczywistości i jakie sa jego konsekwencje. Druga z postaci nierozpoznawania znaczenia czynu dotyczy jego znaczenia aksjologicznego. W takim wypadku poza świadomościa sprawcy pozostaje społeczne znaczenie jego postępowania oraz jego ocena moralna. Sprawca nierozpoznający aksjologicznie swojego czynu nie postrzega go jako nagannego. W wypadku tych dwóch postaci nierozpoznawania znaczenia czynu mamy do czynienia z podobną sytuacja, jak w wypadku dwóch wariantów psychologicznego kryterium niepoczytalności. Otóż, możliwa jest sytuacja, w której sprawca nie rozpoznaje znaczenia swojego czynu zarówno ontologicznie, jak i aksjologicznie. Może być również i tak, że sprawca wie, czego się faktycznie dopuszcza, a więc rozpoznaje znaczenie ontologiczne, nie ocenia tego jednak jako zachowania nieodpowiedniego - brak jest rozpoznania aksjologicznego znaczenia czynu. Niemożliwa jest jednak sytuacja odwrotna, tj. taka, w której sprawca rozpoznawałby aksjologiczne znaczenie czynu, nie wiedząc jednocześnie, co faktycznie czyni ${ }^{7}$.

Przechodząc do kwestii strony podmiotowej czynu zabronionego niepoczytalnego sprawcy, należy przede wszystkim podkreślić, że niepoczytalność w żadnym razie nie wyłącza konieczności ustalenia znamion strony podmiotowej tego czynu. Jak już wspomniano, niepoczytalność jest okolicznościa uniemożliwiającą przypisanie winy. Dopiero gdy ustalimy, że danym czynem wyczerpano wszystkie znamiona typu czynu zabronionego, zarówno strony przedmiotowej, jak i strony podmiotowej, możemy przejść do prawnokarnego wartościowania tego czynu na płaszczyźnie winy, w tym ustalenia, czy był on

${ }^{5}$ Zob. W. Wolter, w: M. Cieślak, K. Spett, W. Wolter, Psychiatria w procesie karnym, Warszawa 1977, s. 27.

${ }^{6}$ Zob. ibidem.

${ }^{7}$ Zob. J. Gierowski, Diagnoza procesów motywacyjnych jako przedmiot opinii sqdowo-psychologicznej, w: J. Stanik (red.), Problemy psychologiczno-psychiatryczne w procesie karnym, Katowice 1985, s. 33 . 
popełniony przez jego sprawcę $\mathrm{w}$ stanie niepoczytalności ${ }^{8}$. Stanowisko takie wyraził również Sąd Najwyższy, gdy wskazywał, że „,w procesie karnym stan psychiczny oskarżonego ma znaczenie dopiero przy ustaleniu, że dopuścił się on czynu zabronionego" 9 .

W doktrynie sformułowano kilka stanowisk dotyczących ustalenia strony podmiotowej czynu niepoczytalnego sprawcy, zwykle przy okazji objaśnianiania zawartości normatywnej art. 31 § 3 k.k. Według pierwszego, reprezentowanego w szczególności przez T. Kaczmarka ${ }^{10}$, ustalenie strony podmiotowej czynu zabronionego popełnionego przez niepoczytalnego sprawcę powoduje znaczne trudności. Różnica między umyślnością a nieumyślnością leży bowiem w sferze zjawisk psychicznych człowieka, których - zdaniem przywołanego autora - nie można analizować u osoby niepoczytalnej ${ }^{11}$.

Twórcą drugiego stanowiska jest M. Tarnawski ${ }^{12}$. Również on przyjmował, że niemożliwe jest ustalenie, czy niepoczytalny sprawca dopuścił się swojego czynu umyślnie czy nieumyślnie, w konsekwencji należy więc uznać, że jedyna możliwą kwalifikacją czynu niepoczytalnego sprawcy jest uznanie tego czynu za przestępstwo nieumyślne ${ }^{13}$ na zasadzie in dubio mitius. W związku z tym, jeżeli w kodeksie karnym nie przewidziano typu nieumyślnego danego przestępstwa, to niepoczytalny sprawca nie może ponosić odpowiedzialności karnej ${ }^{14}$.

Odrębne stanowisko $\mathrm{w}$ przedmiocie analizowanego zagadnienia przedstawił J. Lachowski ${ }^{15}$. Wykluczył on $\mathrm{w}$ ogóle możliwość ustalania umyślności lub nieumyślności przy czynie niepoczytalnego sprawcy, zauważył jednak konieczność dokonania przez sąd kwalifikacji prawnej takiego czynu ${ }^{16}$. Wobec tego należy w kwalifikacji prawnej czynu powołać przepis określający nieumyślny typ czynu zabronionego, jeśli zaś taki nie byłby przewidziany w ustawie karnej, należy przytoczyć przepis określający typ umyślny. Nie oznacza to jednak, zdaniem J. Lachowskiego, że sąd przypisał sprawcy czyn zabroniony popełniony umyślnie lub nieumyślnie, ponieważ czyn ten został popełniony w warunkach niepoczytalności, wobec czego stronę podmiotową czynu zastępuje właśnie ta niepoczytalność ${ }^{17}$.

Odnosząc się do zaprezentowanych wyżej stanowisk, należy się zgodzić z A. Zollem, że nie są one zasadne ${ }^{18}$. Wbrew temu, co twierdzą T. Kaczmarek ${ }^{19}$

8 Zob. A. Zoll, op. cit., s. 10-11.

${ }^{9}$ Wyrok SN z 5 marca 2002 r., III KKN 329/99, ,,Wokanda” 2002, z. 11, s. 14.

10 Zob. T. Kaczmarek, op. cit., s. 44.

11 Zob. ibidem.

12 Zob. M. Tarnawski, op. cit.

${ }^{13}$ M. Tarnawski mówi o przestępstwie, gdyż swoich rozważań dokonuje w odniesieniu do niepoczytalnego sprawcy, który wprawił się w stan nietrzeźwości, lub odurzenia (art. $31 \S 3$ k.k.). W odniesieniu do konstrukcji niepoczytalności z art. $31 \S 1 \mathrm{k} . \mathrm{k}$. powinno się oczywiście mówić o czynie zabronionym.

${ }^{14}$ Zob. M. Tarnawski, op. cit., s. 48, w wypadku niepoczytalności sprawcy uregulowanej w art. 31 $\S 1$ k.k. należałoby wówczas wskazać, że czyn tego sprawcy nie jest czynem zabronionym.

15 Zob. J. Lachowski, op. cit.

16 Zob. ibidem, s. 131.

17 Zob. ibidem, s. 132-133.

18 Zob. A. Zoll, op. cit., s. 14.

19 Zob. T. Kaczmarek, op. cit., s. 44. 
czy M. Tarnawski ${ }^{20}$, u osoby normalnie funkcjonującej zachodzą procesy psychiczne analogiczne do tych zachodzących u niepoczytalnego sprawcy ${ }^{21}$. Oczywiście u osoby niepoczytalnej - na skutek choroby psychicznej, upośledzenia umysłowego lub innego zakłócenia czynności psychicznych - procesy te będą podlegać licznym zniekształceniom, nie uniemożliwia to jednak wnioskowania na ich podstawie o stronie podmiotowej popełnionego czynu. Umyślność bądź nieumyślność niepoczytalnego sprawcy należy więc ustalać podobnie jak przy każdym innym czynie zabronionym. Związane zaś z niepoczytalnością zniekształcenia procesów psychicznych skutkować będą wyłączeniem jego odpowiedzialności karnej dopiero na późniejszym etapie prawnokarnego wartościowania ze względu na niemożność przypisania winy (na podstawie art. $31 \S 1$ k.k.).

Słusznie wskazuje A. Zoll, że rozwiązanie proponowane przez M. Tarnawskiego prowadzi do przyjmowania fikcji nieumyślności czynu niepoczytalnego sprawcy - fikcji, która jest niedopuszczalna ${ }^{22}$ ze względu na konieczność ustalenia, a nie przyjęcia znamion strony podmiotowej. Nie sposób również zgodzić się ze stanowiskiem prezentowanym przez J. Lachowskiego. Przyjmuje on - w mojej ocenie zupełnie dowolnie - że jeśli ustawodawca przewidział nieumyślny typ danego czynu, to w kwalifikacji prawnej należy powołać przepis określający typ nieumyślny, jeżeli zaś przepisu takiego nie ma, to kwalifikacja powinna zawierać przepis regulujący typ umyślny. Nietrafna jest też konstatacja tego autora, że kwalifikacja ta i tak pozostaje bez znaczenia, gdyż strony podmiotowej czynu niepoczytalnego sprawcy nie charakteryzuje umyślność ani nieumyślność, ale właśnie niepoczytalnośćc ${ }^{23}$. J. Lachowski miesza w swoich wywodach dwa odrębne elementy struktury przestępstwa ${ }^{24}$ : płaszczyznę zawinienia, do której przynależy ewentualnie ustalona niepoczytalność, oraz płaszczyznę bezprawności, w ramach której należy sytuować znamiona strony podmiotowej. Jak już bowiem wskazano powyżej, prawnokarne wartościowanie czynu pod względem winy jego sprawcy jest następcze względem ustalenia, że wypełnione zostały znamiona czynu zabronionego, w tym ustalenia znamion strony podmiotowej. Słusznie wskazuje A. Zoll, że k.k. z 1997 r. ,w sposób jednoznaczny oddziela od siebie stronę podmiotową czynu zabronionego, więc znamiona charakteryzujące umyślność albo jej brak, od winy rozumianej normatywnie, jako zarzut popełnienia czynu zabronionego (umyślnego albo nieumyślnego)"25.

A. Zoll, sprzeciwiając się prezentowanym wyżej stanowiskom T. Kaczmarka, M. Tarnawskiego i J. Lachowskiego, wskazuje również, że braku możliwości rozpoznania znaczenia czynu, który może występować u niepoczytalnego sprawcy, nie należy utożsamiać z brakiem świadomości realizacji znamion

${ }^{20}$ Zob. M. Tarnawski, op. cit., s. 48.

${ }^{21}$ Zob. J. Gierowski, op. cit., s. 37.

${ }^{22}$ Zob. A. Zoll, op. cit., s. 13 i 15.

${ }^{23}$ Zob. J. Lachowski, op. cit., 31-33.

${ }^{24}$ Zob. A. Zoll, Kwalifikacja prawna..., s. 14. Zaznaczyć należy, że zdaniem A. Zolla znamiona strony podmiotowej należy sytuować w płaszczyźnie karalności (por. A. Zoll, O normie prawnej z punktu widzenia prawa karnego, „Krakowskie Studia Prawnicze” 23, 1990, s. 81).

${ }^{25}$ Zob. A. Zoll, Kwalifikacja prawna..., s. 9-10. 
czynu zabronionego ${ }^{26}$. Osoba niepoczytalna niemogąca rozpoznać znaczenia swego czynu może bowiem działać ze świadomością realizacji znamion czynu zabronionego ${ }^{27}$. Może też jednak działać bez takiej świadomości. Jak już bowiem wspomniano, niepoczytalny sprawca może przecież nie rozpoznawać ontologicznego znaczenia czynu. W wypadku nierozpoznania ontologicznego czynu sprawca nie zdaje sobie sprawy z tego, co w rzeczywistości czyni. Na przykład niepoczytalny sprawca, u którego występują omamy wzrokowe w majaczeniu drżennym (delirium tremens ${ }^{28}$ ), widzi przedmioty lub postacie w rzeczywistości nieistniejące. Możliwe jest wówczas zabicie przez niego człowieka w błędnym przekonaniu, że walczy np. z demonem czy też z jakimś zwierzęciem. Pojawia się pytanie, jak wówczas oceniać pod względem strony podmiotowej zachowanie takiej osoby, która wprawdzie chciała zabić, ale nie człowieka tylko wyimaginowaną przez swoją zaburzoną psychikę postać. Nie będzie to już sytuacja analogiczna do błędu co do bezprawności, który - jak wskazuje A. Zoll- nie powoduje zmian w stronie podmiotowej ${ }^{29}$, ale raczej analogiczna do błędu co do znamion, który wyłącza możliwość odpowiedzialności za przestępstwo umyślne. W sytuacji takiej zasadne wydawać by się mogło stanowisko M. Tarnawskiego nakazujące przyjmować każdorazowo nieumyślność czynu niepoczytalnego sprawcy. Jak już jednak wykazano, stanowisko to jest błędne. Nieumyślność bowiem można przyjąć po uprzednim wykazaniu - na podstawie art. 9 § 2 k.k. braku zamiaru po stronie sprawcy, naruszenia reguł ostrożności oraz możliwości przewidzenia popełnienia czynu zabronionego, nie zaś automatycznie przyjmować tylko ze względu na stan niepoczytalności sprawcy. Nasuwa się natomiast pytanie, czy w powołanym powyżej przykładzie (dokonania zabójstwa pod wpływem omamów) możemy w ogóle mówić o czynie. Z pytaniem tym wiąże się bardzo ściśle druga kwestia: Czy można mówić o czynie zabronionym w wypadku zachowania niedowolnego?

Z. Ziembiński wskazywał, że racjonalny normodawca powinien stanowić tylko takie normy, które nakazują lub zakazuja zachowań dowolnych zależnych od woli danego człowieka, tj. takich, które można określić mianem postępowania $^{30}$. Słusznie zauważa $€$. Pohl, że tak rozumiana norma wyłączałaby możliwość popełnienia czynu zabronionego przez niepoczytalnego sprawcę, którego zachowanie trudno uznać za dowolne ${ }^{31}$. Proponuje on zatem korektę schematu ujęcia normy prawnej przyjmowanego przez Z. Ziembińskiego, tzn. mówi o ,,...] przesunięciu warunku dowolności zachowania z zakresu normowania prawnokarnej normy sankcjonowanej do zakresu zastosowania normy ją sankcjonującej” ${ }^{32}$. Dzięki takiej korekcie norma sankcjonowana może być również przekroczona zachowaniem niedowolnym, w tym także zachowaniem niepoczytalnego sprawcy. Nadto Ł. Pohl postuluje sytuowanie

${ }^{26}$ Zob. ibidem, s. 14.

27 Zob. ibidem.

${ }^{28}$ Zob. L. Cierpiałkowska, Psychopatologia, Warszawa 2007, s. 138.

${ }^{29}$ Zob. A. Zoll, Kwalifikacja prawna..., s. 14.

${ }^{30}$ Zob. Z. Ziembiński, Problemy podstawowe prawoznawstwa, Warszawa 1980, s. 122.

${ }^{31}$ Zob. Ł. Pohl, Struktura normy sankcjonowanej w prawie karnym. Zagadnienia ogóle, Poznań 2007, s. $81-82$.

${ }^{32}$ Ibidem, s. 82 . 
znamion strony podmiotowej czynu zabronionego w zakresie normy sankcjonowanej. Uważa, że ,,[..] norma sankcjonowana w prawie karnym jest charakteryzowana nie tylko poprzez znamiona przedmiotowe czynu, lecz także poprzez jego znamiona podmiotowe" ${ }^{33}$. Wobec tego Ł. Pohl proponuje następujący schemat normy: „Zakazuje się podmiotowi $\mathrm{X}$ w sytuacji S umyślnie/nieumyślnie wykonać czyn C" ${ }^{34}$.

O celowości wyżej przedstawionej korekty wypowiedział się W. Patryas. Wskazał, że możliwe są dwie interpretacje koncepcji normy prawnej Z. Ziembińskiego ${ }^{35}$. Pierwsza z nich - tzw. słaba interpretacja -zakłada, że stan lub reakcję podmiotu można określić mianem postępowania, gdy w zasadzie zależne są one od woli tego podmiotu, ,,[...] to znaczy gdy wiele jednostkowych wypadków stanu (reakcji) tego rodzaju ma charakter wolicjonalny, chociaż występuja również wypadki, które od woli ludzkiej nie zależą"36. Według interpretacji mocnej, stan lub reakcja podmiotu ,,[... jest postępowaniem, gdy absolutnie wszystkie jego jednostkowe wypadki maja wolicjonalny charakter" ${ }^{37}$. Zdaniem W. Patryasa schemat ujęcia normy prawnej przyjmowany przez Z. Ziembińskiego wymaga zaproponowanej przez Ł. Pohla korekty tylko przy przyjęciu mocnej interpretacji. W wypadku zaś interpretacji słabej koncepcja Z. Ziembińskiego nie wymaga korygowania ${ }^{38}$. W. Patryas zgłosił również zastrzeżenie do sytuowania przez Ł. Pohla znamion strony podmiotowej $\mathrm{w}$ dyspozycji normy sankcjonowanej przy jednoczesnym przenoszeniu warunku dowolności czynu do zakresu zastosowania normy sankcjonującej, wskazując na niespójność takiego rozwiązania ${ }^{39}$. Jeśli bowiem przyjąc skorygowany schemat normy zaproponowany przez Ł. Pohla, to - zdaniem W. Patryasa - uznać należy, że norma sankcjonowana odpowiadająca takiemu schematowi zakazuje wyłącznie czynów umyślnych lub nieumyślnych. Nie zabrania zaś czynów niedowolnych ${ }^{40}$. Wobec tego ,,[...] umieszczanie w normie sankcjonującej wymogu dowolności czynu okazuje się zbędne" ${ }^{41}$. Stanowisko W. Patryasa oparte jest na założeniu, że czyny umyślne sa zawsze czynami dowolnymi. Zatem jego zdaniem wymóg dowolności w schemacie przyjmowanym przez Ł. Pohla znajduje się $\mathrm{w}$ normie sankcjonowanej, co zaprzecza celowości dokonywanej przez niego korekty ${ }^{42}$.

${ }^{33}$ Ł. Pohl, W odpowiedzi na uwagi prof. Wojciecha Patryasa o artykule Eukasza Pohla Norma sankcjonowana w prawie karnym jako przykład normy prawnej nie będącej normą postępowania, ,Ruch Prawniczy, Ekonomiczny i Socjologiczny" 2006, z. 4, s. 174.

${ }^{34}$ Zob. Ł. Pohl, Uwagi na marginesie dialogu z prof. Wojciechem Patryasem, „Ruch Prawniczy, Ekonomiczny i Socjologiczny" 2006, z. 4, s. 183.

${ }^{35}$ Zob. W. Patryas, „Norma sankcjonowana w prawie karnym...” - kilka uwag do artykutu Łukasza

Pohla, „Ruch Prawniczy, Ekonomiczny i Socjologiczny” 2006, z. 1, s. 65.

36 Ibidem.

37 Ibidem.

${ }^{38}$ Ibidem, s. 66.

39 Zob. W. Patryas, Na polemike dra Łukasza Pohla - odpowiedź, „Ruch Prawniczy, Ekonomiczny i Socjologiczny" 2006, z. 4, s. 180.

${ }^{40}$ Zob. W. Patryas, Jeszcze $w$ sprawie normy sankcjonowanej $w$ prawie karnym, „Ruch Prawniczy, Ekonomiczny i Socjologiczny" 2006, z. 4, s. 188.

41 Ibidem.

${ }^{42}$ Ibidem, s. 189. 
Założenie W. Patryasa o dowolności wszystkich czynów umyślnych jest, $\mathrm{w}$ mojej ocenie, nieuprawnione. Wiąże się z innym założeniem, że czyny niepoczytalnego sprawcy, popełnione przez niego umyślnie są zarazem dowolne ${ }^{43}$. Tak jednak nie jest. Każdy bowiem czyn niepoczytalnego sprawcy, także ten popełniony umyślnie, jest niedowolny ${ }^{44}$. O dowolności bowiem nie sposób mówić, gdy sprawca nie może pokierować swoim postępowaniem, a sytuacja taka ma zawsze miejsce $\mathrm{w}$ wypadku niepoczytalności. Zasadne jest jednak twierdzenie, że również niezdolny do pokierowania swoim czynem sprawca (a więc sprawca niepoczytalny) może chcieć lub nie chcieć popełnienia czynu zabronionego, względnie godzić się na jego popełnienie. U niepoczytalnego sprawcy, podobnie jak u każdego człowieka, zachodzą procesy wolicjonalne. Tyle tylko, że procesy te podlegaja zniekształceniom na skutek choroby psychicznej, upośledzenia umysłowego lub innego zakłócenia czynności psychicznych. Stąd też mimo zachodzących procesów wolicjonalnych u niepoczytalnego sprawcy, pozwalających przypisać mu umyślność bądź nieumyślność, nie można mówić o dowolności jego zachowania, brak tu bowiem suwerenności jego woli, wyłączonej przez chorobę psychiczną, upośledzenie umysłowe lub inne zakłócenie czynności psychicznych.

Skoro więc czyn umyślny może być jednocześnie czynem niedowolnym, to zasadne jest przyjęcie za Ł. Pohlem sytuowania wymogu dowolności w zakresie zastosowania normy sankcjonującej. Nie ma wówczas przeszkód, by uznać, że nie musi być dowolności, aby mówić o czynie zabronionym.

O tym, że niepoczytalny sprawca swoim niedowolnym zachowaniem się może dopuścić się czynu zabronionego, informuje nas również art. $94 \S 1$ k.k. Zgodnie z jego treścią: „Jeżeli sprawca, w stanie niepoczytalności określonej $\mathrm{w}$ art. $31 \S 1$, popełnił czyn zabroniony [wyróż. - M.K.] o znacznej społecznej szkodliwości i zachodzi wysokie prawdopodobieństwo, że popełni taki czyn ponownie, sąd orzeka umieszczenie sprawcy w odpowiednim zakładzie psychiatrycznym". Zastosowanie więc wobec niepoczytalnego sprawcy środka zabezpieczającego jest każdorazowo uzależnione od stwierdzenia popełnienia przez niego czynu zabronionego ${ }^{45}$.

Należy się zgodzić z Ł. Pohlem, że: „Błąd Z. Ziembińskiego sprowadza się, zatem do tego, że zachowaniu normowanemu narzuca wymóg, który jest dlań wymogiem przypisania winy" ${ }^{46}$. Niepoczytalnemu sprawcy nie można przypisać winy właśnie dlatego, że działa on niedowolnie. Gdyby zaś zająć stanowisko przeciwne, tj. uznać, że zachowaniem niedowolnym nie można naruszyć normy sankcjonowanej, to należałoby również uznać za niepotrzebną regulację $\mathrm{z}$ art. $31 \S 1 \mathrm{k} . \mathrm{k}$. Niedowolne zachowanie niepoczytalnego sprawcy nie byłoby bowiem wówczas czynem zabronionym.

Również K. Daszkiewicz zwróciła uwagę, że w prawie karnym czyn nie zawsze oznacza dowolne zachowanie się człowieka ${ }^{47}$. Zachowaniem

${ }^{43}$ Zob. W. Patryas, Jeszcze $w$ sprawie..., s. 189, przyp. 3.

${ }^{44}$ Zob. K. Daszkiewicz, w: Z. Ziembiński, K. Daszkiewicz, S. Sołtysiński, Trójgtos o prawniczym pojęciu czynu, „Studia Prawnicze” 1971, z. 29, s. 30 i Ł. Pohl, Norma sankcjonowana..., s. 59.

${ }^{45}$ Stwierdzenie to zaś wymaga ustalenia znamion strony podmiotowej tego czynu.

${ }^{46}$ Ł. Pohl, Norma sankcjonowana $w$ prawie karnym, „Ruch Prawniczy, Ekonomiczny i Socjologiczny" 2006, z. 1, s. 59.

${ }^{47}$ Zob. K. Daszkiewicz, w: Z. Ziembiński, K. Daszkiewicz, S. Sołtysiński, op. cit., s. 30. 
niedowolnym jest bowiem zachowanie się osoby niepoczytalnej, które uznaje się jednak za czyn. Zauważa tu jednak niekonsekwencje w postaci wyłączania z pojęcia czynu zachowań osób znajdujących się pod wpływem vis absoluta ${ }^{48}$. Zgodzić by się tu należało z M. Rodzynkiewiczem, który stwierdza, że wyłączenie to jest efektem pewnych względów aksjologicznych czy socjotechnicznych ${ }^{49}$, i wskazuje za Z. Ziembińskim, iż ,,[...] w dyskursie prawniczym dobieramy sobie taki sposób rozumienia pewnych pojęć, który usprawiedliwiałby pewne rozwiązania problemów praktycznych" ${ }^{50}$. Stąd też można przyjąć, że niedowolne zachowanie niepoczytalnego sprawcy jest czynem zabronionym, co pozwala np. na zastosowanie środka zabezpieczającego na podstawie art. 94 $\S 1$ k.k., podczas gdy zachowanie niedowolne ze względu na vis absoluta czynem w prawie karnym już nie jest.

Na takie stwierdzenie pozwala również skutkowe ujęcie czynu i jednocześnie popiera je znacznie silniejszymi argumentami. Według tego ujęcia: ,,[... o tym, jaki czyn wykonał podmiot, decyduje wytworzony przez niego stan rzeczy, a więc, X wykonał czyn C, gdy wytworzył stan rzeczy C"51. Czyn jest tu pojmowany możliwie najszerzej. Po dokonaniu jednak wyłączeń z zakresu czynu stanów rzeczy wytworzonych odruchami bezwarunkowymi, tzw. ruchami refleksyjnymi, czy wytworzonych podczas wyłączenia stanu czuwania ${ }^{52}$ otrzymamy klasę zachowań dowolnych i niedowolnych, które mogą stanowić przedmiot wartościowania prawnokarnego.

Po dokonaniu powyższych ustaleń powróćmy do przykładu niepoczytalnego sprawcy dokonującego zabójstwa $\mathrm{w}$ delirium tremens $\mathrm{z}$ silnymi omamami. Z pewnością zachowanie takiego sprawcy będzie niedowolne. Nie wyklucza to jednak uznania jego zachowania za czyn, a w drodze dalszego prawnokarnego wartościowania - za czyn zabroniony. Warunek dowolności usytuowany w zakresie zastosowania normy sankcjonującej jest bowiem warunkiem następczym względem ustalenia wypełniania znamion czynu zabronionego, $\mathrm{w}$ tym znamion strony podmiotowej. Wydaje się jednak, że wyłączona jest możliwość przypisania takiemu sprawcy umyślności. Nie rozpoznaje on bowiem faktycznego znaczenia tego, co czyni. Innymi słowy, nie wie, co czyni - nie wie, że zabija człowieka. W jego świadomości nie znajdują odbicia znamiona strony przedmiotowej, a jest to warunkiem sine qua non umyślności. Aspekt intelektualny zamiaru, zarówno bezpośredniego, jak i ewentualnego, polega bowiem na przewidywaniu możliwości popełnienia czynu zabronionego ${ }^{53}$. Przewidywanie to wymaga odzwierciedlenia się $\mathrm{w}$ świadomości sprawcy tych elementów rzeczywistości, które są desygnatami okoliczności przedmiotowych danego czynu. Omawiany sprawca w delirium tremens musiałby więc zdawać

${ }^{48}$ Zob. ibidem; podobnie A. Zębik, Czyn przestęny w polskim prawie karnym, ,Zeszyty Naukowe Akademii Spraw Wewnętrznych" 1974, z. 4, s. 165-166.

${ }^{49}$ Zob. M. Rodzynkiewicz, Modelowanie pojęć w prawie karnym, Kraków 1988, s. 32.

${ }^{50}$ Ibidem, s. 36.

${ }^{51}$ W. Patryas, Interpretacja karnistyczna. Studium metodologiczne, Poznań 1988, s. 14.

${ }^{52}$ Zob. Ł. Pohl, Struktura normy..., s. 87. Ł. Pohl skutkowe ujęcie czynu po dokonaniu takiego zabiegu określa umiarkowaną wersją skutkowego ujęcia czynu lub po prostu racjonalnym jego ujęciem.

${ }^{53}$ Aby prowadzone tu rozważania były kompletne, należy jeszcze dodać, że w wypadku zamiaru bezpośredniego jego aspekt intelektualny może przyjmować postać świadomości konieczności zrealizowania znamion czynu zabronionego. 
sobie sprawę $\mathrm{z}$ tego, że jego zachowanie jest $\mathrm{w}$ rzeczywistości zabijaniem człowieka. Jego stan wyklucza jednak taką świadomość, a tym samym wyklucza też przypisanie mu umyślności.

Zgodzić się należy zatem z poglądem zaprezentowanym przez A. Liszewską, że jeśli sprawca nie rozpoznaje znaczenia swojego czynu w warstwie ontologicznej, to o umyślności mowy rzeczywiście być nie może. Nieprawidłowe jest jednak stwierdzenie tej autorki, że niepoczytalność staje się w tym zakresie okolicznością wyłączająca umyślność, a nie winę i na poparcie tak postawionej tezy wskazywanie na analogię do regulacji błędu co do znamion z art. 28 $\S 1$ k.k. ${ }^{54}$ Umyślność $\mathrm{w}$ wypadku nierozpoznawania ontologicznego znaczenia czynu wyłączona zostaje przez samą swoją konstrukcję wyrażoną w przepisie art. $9 \S 1$ k.k. Jak już bowiem wskazywano, umyślność w każdej ze swych postaci kreowanych w art. $9 \S 1 \mathrm{k} . \mathrm{k}$. wymaga świadomości możliwości realizacji przedmiotowych znamion czynu zabronionego. Gdy takiej świadomości brak, o umyślności mowy być nie może. W wypadku gdy sprawca nie wie, czym w rzeczywistości jest jego czyn, nie można zasadnie twierdzić, że swoja świadomością obejmuje popełnienie tego czynu. W świadomości sprawcy nie znajduja bowiem odbicia rzeczywiste znamiona realnie popełnianego przez niego czynu. Zostaja one patologicznie zniekształcone w zaburzonym stanie psychicznym sprawcy i nie stanowią tym samym mentalnego odpowiednika przedmiotowych znamion danego czynu zabronionego, bądź też w ogóle nie sa dopuszczane do świadomości sprawcy ${ }^{55}$.

Sytuacja taka rzeczywiście jest analogiczna do błędu z art. $28 \S 1$ k.k. Obrazującym ją przykładem może być właśnie niepoczytalny sprawca w delirium tremens zabijający człowieka. Zwrócić jednak trzeba uwagę, że o nierozpoznawaniu ontologicznego znaczenia czynu należy również mówić w sytuacji nieco odmiennej. Mianowicie niepoczytalny sprawca może wprawdzie wiedzieć, co faktycznie czyni - jest świadomy istoty swojego zachowania, ale nie zauważa jego powiązań kauzalno-skutkowych. W świadomości sprawcy może znaleźć odzwierciedlenie okoliczność, że przykładowo dodaje do posiłku innej osoby truciznę. Sprawca może być świadom, że jest to trucizna oraz że spożyje ją inna

${ }^{54}$ Zob. A. Liszewska, op. cit., s. 637. Na analogię między niemożnością rozpoznania ontologicznego znaczenia czynu a błędem z art. 28 § 1 k.k. wskazywał również A. Zoll, w: idem. (red.), Kodeks karny. Część ogólna. Komentarz, t. 1, Kraków, s. 559. Słuszne są uwagi części doktryny (zob. Ł. Pohl, Prawo karne. Wykład części ogólnej, Warszawa 2012, s. 331), że przepis art. 28 § 1 k.k. regulujący instytucję tzw. błędu co do znamion jest przepisem zbędnym w obowiązującym Kodeksie karnym. Podobnie jak w sytuacji nierozpoznawania ontologicznego znaczenia czynu, przyjęcie umyślności w wypadku błędu co do okoliczności stanowiącej znamię czynu zabronionego zostaje wyłączone ze względu na regulację samej umyślności zawartą w art. $9 \S 1$ k.k.

${ }^{55} \mathrm{Na}$ marginesie przedstawianych tu rozważań zauważyć należy, że również sprawcy, który wprawdzie nie rozpoznaje tego, co faktycznie czyni, ale nie jest uznany za niepoczytalnego w świetle art. $31 \S 1$ k.k., nie będzie można przypisać umyślnego popełnienia czynu zabronionego. Niespełniony pozostanie bowiem wymóg ustalenia intelektualnego aspektu umyślności. Sytuacja taka może mieć miejsce np. wtedy, gdy nie występuje psychiatryczne kryterium niepoczytalności, tj. przyczyną nierozpoznawania ontologicznego znaczenia czynu nie jest choroba psychiczna, upośledzenie umysłowe ani inne zaburzenie czynności psychicznych. Umyślność może zostać wyłączona również ze względu na niepełne rozpoznanie faktyczne znaczenia czynu, a tym samym niepełną świadomość sprawcy co do znamion przedmiotowych czynu w wypadku stanu poczytalności znacznie ograniczonej - uregulowanego w art. $31 \S 2$ k.k. Podobnie w wypadku sprawcy, który dopuścił się czynu w stanie niepoczytalności spowodowanej wprawieniem się w stan nietrzeźwości lub odurzenia, nie będzie można mówić o umyślnym popełnieniu czynu zabronionego, jeśli nie rozpoznawał on ontologicznego znaczenia tego czynu. 
osoba, ale nie obejmować jednak swoją zaburzoną świadomością skutku takiej sytuacji. Można nawet założyć, że postawa wolicjonalna sprawcy względem tego, co robi, przejawia się w chęci albo zgodzie ${ }^{56}$. Chęć ta jednak nie może obejmować nieuświadamianych sobie przez sprawcę następstw jego czynu. Również i w tym wypadku brak jest konstytutywnego dla umyślności odbicia wszystkich znamion przedmiotowych w świadomości sprawcy - poza nia pozostaje bowiem znamię skutku ${ }^{57}$.

O wykluczeniu umyślności można więc będzie mówić w wypadku niepoczytalności zawsze wtedy, gdy sprawca nie rozpoznawał ontologicznego znaczenia swojego czynu. Co się z tym wiąże, nie rozpoznawał go również aksjologicznie oraz nie mógł pokierować swoim postępowaniem. Powstaje zatem pytanie, jak w takim wypadku zakwalifikować taki czyn oraz czy możliwe będzie zastosowania środków zabezpieczających na podstawie art. $94 \S 1$ k.k.

Jak już wcześniej wskazywano, nie można przyjmować automatycznie nieumyślności po stronie takiego sprawcy. Konieczne jest do tego - zgodnie z art. $9 \S 2$ k.k. - wykazanie naruszenia reguł ostrożności oraz przewidywania bądź możliwości przewidywania popełnienia czynu zabronionego. Ustalenie takich elementów po stronie podmiotowej niepoczytalnego sprawcy może być często niemożliwe. Sprawca niezdolny do rozpoznania faktycznego znaczenia swojego czynu nie przewiduje zarazem jego popełnienia (wykluczona więc zostaje tzw. świadoma nieumyślność) oraz może w ogóle nie mieć możliwości takiego przewidywania. $\mathrm{W}$ tym miejscu pojawia się pytanie o kryterium, jakim należy się przy ustalaniu owej możliwości posłużyć. Mianowicie czy powinno to być kryterium w pełni obiektywne - ustalane na podstawie możliwości osoby o niezaburzonej psychice, czy też zobiektywizowane, ale uwzględniające stan psychiczny osoby niepoczytalnej. W kontekście stopni struktury przestępstwa, w której płaszczyzna winy i wiążąca się z nią ewentualna niepoczytalność sa następcze względem ustalenia znamion czynu zabronionego, w tym znamion strony podmiotowej, udzielenie odpowiedzi na to pytanie nastręcza znaczących trudności.

Jeśliby jednak można było zachowanie się niepoczytalnego sprawcy zakwalifikować jako popełnienie nieumyślnego czynu zabronionego, to sprawca taki nie poniesie odpowiedzialności karnej. Dopiero na tym etapie zastosowanie znajdzie art. $31 \S 1$ k.k. i wyłączona ze względu na niepoczytalność zostanie wina sprawcy. Gdyby jednak niepoczytalnemu sprawcy nie można było

${ }^{56} \mathrm{Z}$ podobną sytuacją będziemy mieli do czynienia np. w wypadku niepoczytalnego sprawcy, który swoim zachowaniem sprowadza bezpośrednie niebezpieczeństwo pożaru. Niepoczytalny sprawca może wiedzieć, co rzeczywiście robi (np. rozlewa benzynę i podkłada ogień), nawet tego chcieć, a jednocześnie nie zdawać sobie sprawy w swojej zaburzonej psychice, do czego to prowadzi.

${ }^{57}$ Wydaje się zatem, że nierozpoznanie ontologicznego znaczenia czynu jest stopniowalne. Zachodzi bowiem wyraźna różnica w przytoczonych przykładach pozbawienia człowieka życia przez niepoczytalnych sprawców - działającego pod wpływem omamów oraz dodającego truciznę. Stopniowalna jest również niepoczytalność w ogóle. Funkcjonowanie psychiczne sprawcy o umiarkowanym stopniu upośledzenia umysłowego jest mniej zaburzone niż sprawcy, który jest upośledzony umysłowo w stopniu głębokim. Przy lekkim upośledzeniu umysłowym zaś przyjmuje się zazwyczaj poczytalność ograniczoną. Trzeba wskazać tu na pewną niekonsekwencję - lekki stopień upośledzenia odpowiada wiekowi umysłowemu w najlepszym razie 12-latka. Natomiast w polskim prawie karnym zgodnie z treścią art. 10 $\S 1$ k.k. do ponoszenia odpowiedzialności karnej zdolna jest osoba, która ukończyła 17 lat. W świetle tego przepisu nieuprawnione wydaje się przypisywanie winy $\mathrm{w}$ popełnieniu czynu zabronionego, nawet znaczenie umniejszonej, osobie o lekkim stopniu upośledzenia umysłowego. 
z jakichkolwiek względów przypisać popełnienia nieumyślnego czynu zabronionego lub czyn taki nie został w kodeksie stypizowany jako możliwy do popełnienia $\mathrm{w}$ formie strony podmiotowej charakteryzującej się nieumyślnościa, to zgodnie z obecnym brzmieniem art. $94 \S 1$ k.k. nie będzie można wobec takiego sprawcy zastosować środka zabezpieczającego w postaci umieszczenia go w odpowiednim zakładzie psychiatrycznym. Nie ma bowiem wystarczających podstaw, by przyjąć - jak czyni to część doktryny ${ }^{58}$ - że pojęcie czynu zabronionego w kontekście art. $94 \$ 1$ k.k. należy rozumieć jedynie jako znamiona strony przedmiotowej czynu. W art. $115 \S 1$ k.k. ustawodawca, wyjaśniając pojęcie czynu zabronionego, wprost wskazał, że jest to zachowanie o znamionach określonych $\mathrm{w}$ ustawie karnej. Czynu zabronionego można dopuścić się zatem, realizując zarówno jego znamiona przedmiotowe, jak i podmiotowe. Propozycja, by czynić wyjątek w rozumieniu wyrażenia „czyn zabroniony" w art. $94 \S 1$ k.k. na potrzeby stosowania środków zabezpieczających, wymaga przyzwolenia na niekonsekwencję w rozumieniu pojęcia czynu zabronionego oraz jest trudna do zaakceptowania $\mathrm{z}$ punktu widzenia zasad praworządności ${ }^{59}$. W omawianej sytuacji podstawą prawną umieszczenia osoby niepoczytalnej w zakładzie psychiatrycznym moga być jedynie przepisy ustawy z 19 sierpnia 1999 r. o ochronie zdrowia psychicznego ${ }^{60}$.

Przechodząc do omawiania pozostałych możliwych wypadków niepoczytalności, stwierdzić trzeba, że nierozpoznawanie przez sprawcę znaczenia czynu jedynie na płaszczyźnie aksjologicznej nie wyłącza w żadnym stopniu możliwości przypisania umyślności. W pełni możliwa jest sytuacja, że sprawca uświadamia sobie, co czyni, i chciał tego albo godził się na to, a jednocześnie nie postrzegał tego jako zachowania nagannego czy naruszającego jakiekolwiek normy. Nieodparcie nasuwa się tutaj analogia do błędu co do bezprawności. Wyłączenie winy nastąpi jednak, oczywiście przy spełnieniu psychiatrycznego kryterium niepoczytalności, na podstawie art. $31 \S 1$ k.k., nie zaś na podstawie art. 30 k.k.

Nie można zgodzić się z poglądem zaprezentowanym przez A. Liszewską, by druga $\mathrm{z}$ postaci psychologicznego kryterium niepoczytalności - niemożność pokierowania swoim postępowaniem - również wyłączała możliwość przypisania sprawcy umyślnego zrealizowania znamion czynu zabronionego ${ }^{61}$. Autorka ta stwierdza, że: „Sprawca nie ma zamiaru popełnienia czynu zabronionego, jeśli nie może pokierować swoim postępowaniem" ${ }^{62}$. Twierdzenie to wynika ze sposobu postrzegania przez nią umyślności w kontekście możności sterowania swoim zachowaniem zgodnie $\mathrm{z}$ wolą. Jak już jednak wskazywano powyżej, dowolność nie jest warunkiem umyślności. Można bowiem ustalić, czy niepoczytalny sprawca, który nie był w stanie kierować swoim postępowaniem, żywił względem swego czynu postawę wolicjonalną chęci albo zgody. Oczywiście owa chęć lub zgoda nie są suwerennie ukształtowane, są one bowiem wynikiem

${ }^{58}$ Zob. M. Królikowski, w: idem, R. Zawłocki (red.), Kodeks karny. Część ogólna, t. 1, Warszawa 2010, s. 905 .

${ }^{59}$ Zob. T. Przesławski, Funkcja czynnika psychicznego $w$ konstrukcji czynu zabronionego $i$ formach winy, ,Studia Iuridica” 48, 2008, s. 222.

${ }^{60}$ T. jedn.: Dz. U. 2011, Nr 231, poz. 1375.

${ }^{61}$ A. Liszewska, op. cit., s. 638.

62 Ibidem. 
zaburzeń psychicznego funkcjonowania sprawcy (choroby psychicznej, upośledzenia umysłowego lub innego zaburzenia czynności psychicznych). Można jednak jego nastawienie woli zaklasyfikować jako chęć albo zgodę przy zastrzeżeniu, że brak jest suwerenności tej woli, co powodowało, iż sprawca nie mógł sensownie pokierować swoim postępowaniem.

Przy stwierdzeniu, że brak dowolności czynu nie wyłącza umyślności, nieaktualna staje się konstatacja A. Liszewskiej, iż w każdym wypadku stwierdzenia niepoczytalności niemożliwe staje się przypisanie umyślności ${ }^{63}$. Możliwości takiej nie ma w wypadku niemożności rozpoznania ontologicznego znaczenia czynu oraz - zdaniem A. Liszewskiej - zawsze wtedy, kiedy sprawca nie może pokierować swoim postępowaniem. Ponieważ w niepoczytalności kierownictwo takie jest zawsze wyłączone, konstatuje ona, że czyn niepoczytalnego sprawcy będzie mógł być zakwalifikowany tylko jako czyn popełniony nieumyślnie. W świetle powyżej dokonanych ustaleń i rozważań stanowisko takie nie wydaje się jednak w pełni trafne. Umyślność zostaje wyłączona bowiem jedynie $\mathrm{w}$ wypadku nierozpoznawania przez sprawcę faktycznego znaczenia czynu. Możliwe jest natomiast przypisanie umyślnego czynu zabronionego sprawcy nierozpoznającemu swojego czynu aksjologicznie oraz sprawcy niezdolnemu do pokierowania swoim postępowaniem.

Podkreślenia więc raz jeszcze wymaga nie tyle możliwość, ile konieczność ustalenia strony podmiotowej czynu zabronionego niepoczytalnego sprawcy. Wbrew niektórym twierdzeniom ${ }^{64}$ osoba niepoczytalna może bowiem popełnić czyn zabroniony umyślnie lub nieumyślnie. Oczywiście tę umyślność lub nieumyślność należy rozpatrywać w granicach zaburzonej psychiki niepoczytalnego sprawcy. Fakt tych zaburzeń uwzględniony natomiast zostaje w wyłączeniu możliwości przypisania sprawcy winy.

mgr Magdalena Kowalewska

Uniwersytet im. Adama Mickiewicza w Poznaniu

magkow@amu.edu.pl

\section{SUBJECTIVE FEATURES OF A CRIMINAL ACT COMMITTED BY AN INSANE PERPETRATOR}

Summary

This paper concerns the subjective features of a criminal act committed by an insane perpetrator. This problem has been discussed in the Polish doctrine of criminal law on a number of occasions, but no clear answers to some crucial questions has been offered. Thus the attempt to highlight the main concerns and their possible solutions. The issues under review include the essence of insanity, the issue of recognising an insane perpetrator's behaviour as an act in criminal law, the voluntary commission of the act, and, finally, the possibility of attributing mens rea to an insane perpetrator.

63 Ibidem, s. 639.

${ }^{64}$ C. Znamierowski wprost stwierdzał, że niepoczytalni sprawcy: „Nie mogą działać rozmyślnie [...]. Nie są zdolni wobec tego również mieć świadomie zły zamiar" - zob. C. Znamierowski, Wina i odpowiedzialność, Warszawa 1957, s. 116. Zgodzić należy się z C. Znamierowskim o tyle, że nie można u niepoczytalnego sprawcy mówić o ,,świadomym złym zamiarze” (wyróż. - M.K.). Ten brak świadomości jest jednak uwzględniany właśnie przez niemożność przypisania winy niepoczytalnemu sprawcy. 
Copyright of Journal of Law, Economics and Sociology is the property of Faculty of Law and Administration of Adam Mickiewicz University in Poznan and its content may not be copied or emailed to multiple sites or posted to a listserv without the copyright holder's express written permission. However, users may print, download, or email articles for individual use.

Właścicielem praw autorskich do „Ruchu Prawniczego, Ekonomicznego i Socjologicznego” jest Wydział Prawa i Administracji Uniwersytetu im. Adama Mickiewicza w Poznaniu. Zawartość czasopisma nie może być kopiowana, przesyłana do innych stron internetowych bądź zamieszczana na blogach bez pisemnej zgody wydawcy. Niemniej artykuły można drukować, kopiować lub przesyłać w formie elektronicznej na własny użytek. 